\title{
Vulpia myuros (L.) C.C.Gmel (Rat's-tail Fescue) - A Problem Weed in the Rape Crops of Our Country
}

\author{
Mihaela Ioana Georgescu ${ }^{1, *}$, Vasilica Luchian ${ }^{1}$, Liviu Dincă ${ }^{2}$, Daniel Constantin Potor ${ }^{1}$, Octavian Groza \\ ${ }^{1}$ Faculty of Horticulture, University of Agronomic Sciences and Veterinary Medicine of Bucharest, Romania \\ ${ }^{2}$ Faculty of Agriculture, University of Agronomic Sciences and Veterinary Medicine of Bucharest, Romania \\ ${ }^{3}$ Agricover SRL, Cubic Center Building, Romania
}

Copyright $(2016$ by authors, all rights reserved. Authors agree that this article remains permanently open access under the terms of the Creative Commons Attribution License 4.0 international License.

\begin{abstract}
The fact that in a number of locations in Giurgiu, Dâmbovița and Arges County rape crop was severely affected by the presence of the Vulpia myuros species this spring, has led us to take the survey and analyse the premises that favoured the species installation and development. Soil samples and Vulpia plants were taken to establish their characteristics. Soil features correspond to the ecological requirements of the species. The morphometric values recorded on field plant are exceeding the data recorded in the literature. Any herbicide used had no effect on Vulpia plants growth. The establishment by direct seeding of rapeseed crops and bare spots in the field were the precondition for the installation and propagation of Vulpia myuros plants that caused severe harvest decrease.
\end{abstract}

Keywords Rape Crops, Vulpia Myuros, Weed Problem

\section{Introduction}

Vulpia myuros known in our country as a species of dry, rocky places, oligotrophic, xero-mesophyulous, subtermophyllous, moderately-strongly acidophilic [15], was reported as grass weed problem in winter crops in Australia, USA, the Netherlands and Denmark [11].

V.myuros is an annual or winter annual species [7] that multiply only by seed. These survive in the soil a limited period [10]. Seeds germination occurs in autumn, under cool soil temperatures and adequate moisture and, for inflorescence formation and flowering in the following spring, the plant requires a period of vernalization [2].

According to Mathiassen et al. [11], V.myuros plants aren't competitive in a dense crop, but they may be set in bare spots of the fields from where they can infest the area and cause severely crop losses. Control of V.myuros became difficult when crops are established by direct seed systems and so the soil disturbance is low; due to the morphological characteristics (shallow rooted) plants are not affected by the minimum tillage system [2,10].

Ball et al. [2] observations show that reliance on glyphosate for weed control in fallow favored the expansion of this species. The experiences of Min et al. [13] indicate that V.myuros has a high tolerance to a variety of herbicides, due, after Hull et al. [10], its natural tolerance to ACCase inhibiting herbicides. Also, the decomposed residues of $V$. myuros affect adversely the wheat growth because their allopathic substances [3]. Aqueous extracts of rat's tail fescue inhibited seed germination, coleoptile and root growth of wheat [12].

So far, in the literature of our country, Vulpia myuros was mentioned in connection with studies of phytosociology in diverse areas: Bucharest, Codru Moma Montains, meadows of Subcarpathian Ialomița etc. [1, 4, 5, 14]. The main works on segetal flora in our country does not mention the existence of this species as a crops weed $[6,8]$. It is for the first time that this species is recorded as weed in rapeseed in our country (Romania). This article describes the behavior of this species in the particular conditions of three areas in Romania where it was identified.

\section{Materials and Methods}

Observations were conducted in winter rape crops in rural Mihăileşti (Giurgiu County), Mircea Voda (Dâmbovița County) and Mioși (Arges County) where V.myuros infestation caused significant crop losses.

In the fall of 2013, at the setting up the rapeseed crop in Mihăliesti town, soil samples were taken to determine its characteristics $(\mathrm{pH}$, humus, nitrogen, phosphorous and potassium content, $\mathrm{C} / \mathrm{N}$, nitrogen index etc.) and to establish a proper fertilization plan. These data were compared with the ecological requirements of the Vulpia myuros species.

At the time of flowering - June 2014, and at the end of growing season - July 2014, specimens of the $V$. myuros plants were taken from rapeseed crop from Mihăliesti town 
to establish their morphological characters (plant size, inflorescence length, number of flowers / spikelet etc.).

\section{Results and Discussion}

Rapeseed culture was established by direct seeding in all 3 areas.

On the lands of Dâmbovița and Argeș County rapeseed culture has followed after cereal crops. Pictures taken in October on these lands show the degree of invasion by Vulpia myuros plants (Figure 1,2).

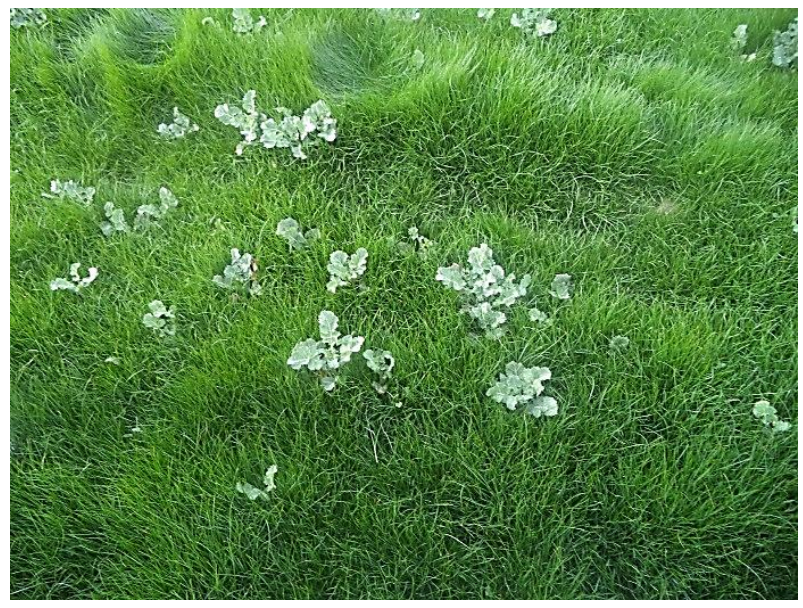

Figure 1. Overview of rape field

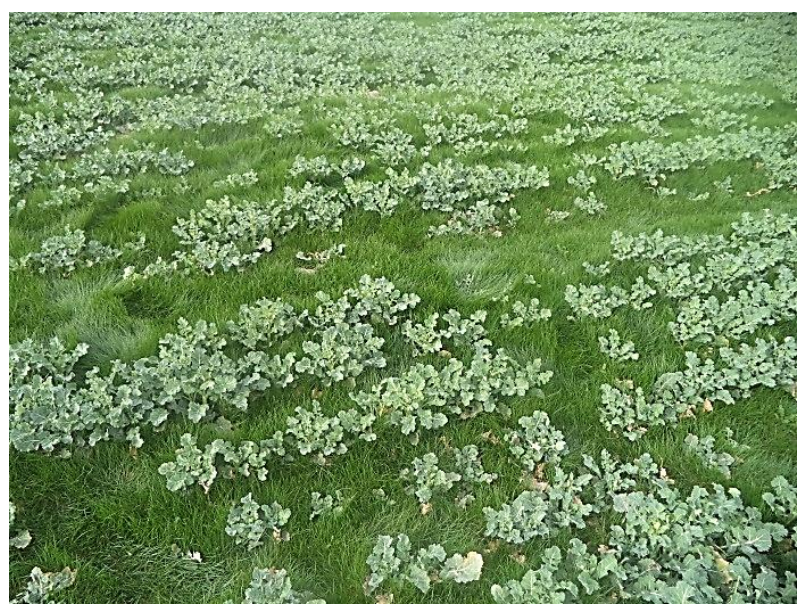

Figure 2. The invasion of Vulpia myuros plants in rape crops

The infestation degree was not reduced by herbicides applied, e.g. Prosper or Agil 100 EC, the last in a dose of 2,5 1/ha.
In the Mihăileşti town the rapeseed crop was established on a land which was fallow until 2013. Data resulted from soil analyses (Tab. 1) have led to the following scheme of fertilization: fall $-400 \mathrm{~kg} / \mathrm{ha} \mathrm{NPK}$ and $200 \mathrm{~kg} / \mathrm{ha} \mathrm{NAC}$; spring: $200 \mathrm{~kg} / \mathrm{ha}$ urea. Rape culture establishment was made by using 60 germinable seeds $/ \mathrm{m}^{2}$. Post emergence herbicide Cleranda was applied.

Soil features correspond to the ecological requirements of the species.

As in the previous cases, Vulpia myuros infestation was observed early as autumn. Spring the herbicide Pulsar 40 application have no effect on Vulpia plants. The appearance of the rapeseed crop in June can be seen in Fig. 3 and 4.

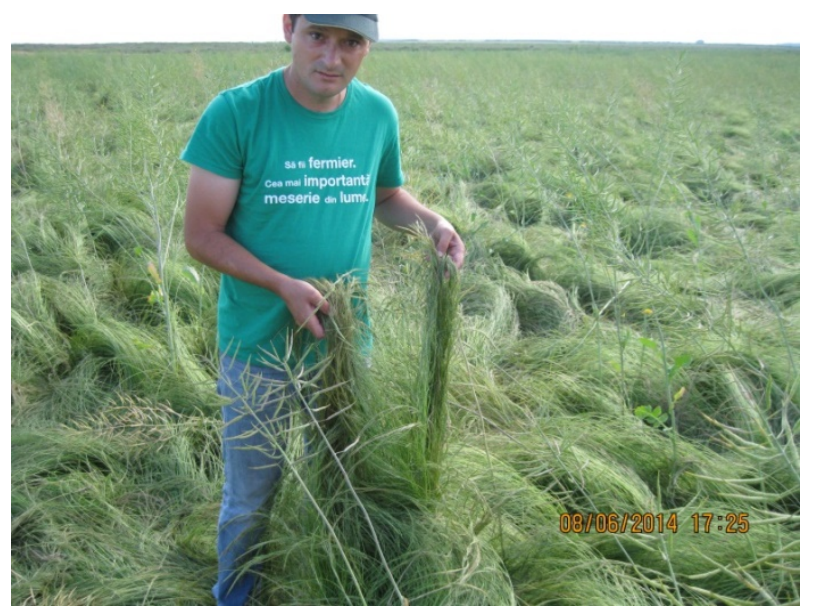

Figure 3. Rapeseed field in June in Mihăileşti town

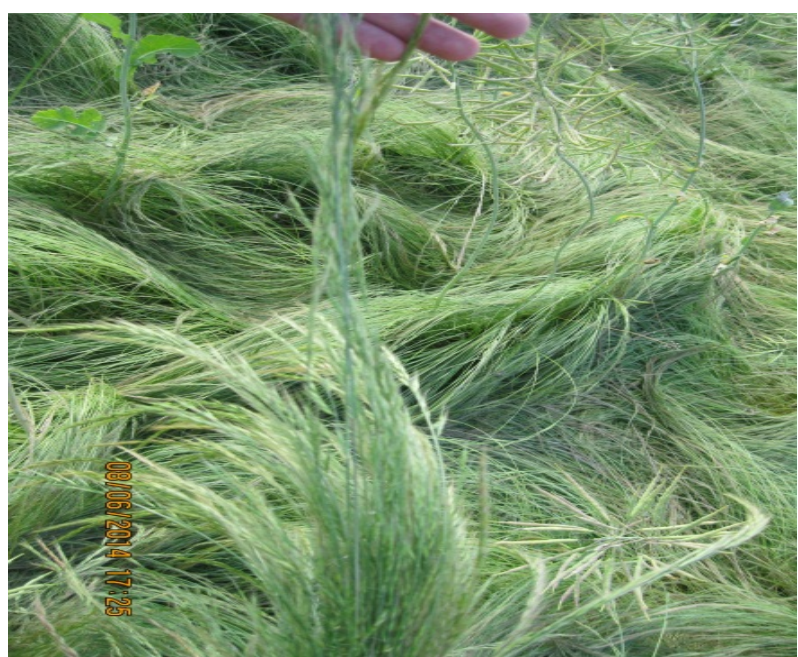

Figure 4. Vulpia myuros and rape plants

Table 1. The main characteristics of Mihăilesti soil

\begin{tabular}{|c|c|c|c|c|c|c|c|c|}
\hline $\begin{array}{c}\mathrm{pH} \\
(0-20 \mathrm{~cm})\end{array}$ & $\begin{array}{c}\text { Humus } \\
\%\end{array}$ & $\begin{array}{c}\mathrm{N} \\
\%\end{array}$ & $\begin{array}{c}\mathrm{K} \\
\mathrm{mg} / \mathrm{kg}\end{array}$ & $\begin{array}{c}\mathrm{P} \\
\mathrm{mg} / \mathrm{kg}\end{array}$ & $\begin{array}{c}\mathrm{V} \\
\%\end{array}$ & $\mathrm{IN}$ & $\begin{array}{c}\mathrm{T} \\
\mathrm{m} . \mathrm{e} / 100 \mathrm{~g} \text { soil }\end{array}$ & $\mathrm{C} / \mathrm{N}$ \\
\hline 5,356 & 2,46 & 0,143 & 170 & 32,50 & 77.04 & 1,90 & 20,93 & 9,99 \\
\hline $\begin{array}{c}\text { moderately } \\
\text { acid }\end{array}$ & medium & medium & good & medium & medium & $\begin{array}{c}\text { low } \\
\text { nitrogen supply }\end{array}$ & medium & $\begin{array}{c}\text { high } \\
\text { fertility }\end{array}$ \\
\hline
\end{tabular}

$\mathrm{pH}$ - soil reaction; $\mathrm{N}$ - total nitrogen content; $\mathrm{K}$ - potassium content; $\mathrm{P}$ - phosphorus content; $\mathrm{V} \%$ - the degree of base saturation;

$\mathrm{IN}$ - nitrogen index; $\mathrm{T}$ - cation exchange capacity; $\mathrm{C} / \mathrm{N}$ - cellulosic substances/protein substances 
Morphometric data of Vulpia plants harvested from Mihăileşti rapeseed culture were compared with existing data in the literature of our country [9] (Table 2).

Table 2. Morphometric data of Vulpia myuros plants from field observation and literature

\begin{tabular}{|c|c|c|c|c|c|c|c|c|}
\hline $\begin{array}{c}\text { The main } \\
\text { morphometric data }\end{array}$ & $\begin{array}{c}\text { Plant } \\
\text { size } \\
(\mathrm{cm})\end{array}$ & $\begin{array}{c}\text { Inflorescence } \\
\text { length }(\mathrm{cm})\end{array}$ & $\begin{array}{c}\text { Spikelet } \\
\text { length }(\mathrm{mm})\end{array}$ & $\begin{array}{c}\text { Upper } \\
\text { glume } \\
\text { length }(\mathrm{mm})\end{array}$ & $\begin{array}{c}\text { Lower } \\
\text { glume } \\
\text { length }(\mathrm{mm})\end{array}$ & $\begin{array}{c}\text { Lemmas } \\
\text { length } \\
(\mathrm{mm})\end{array}$ & $\begin{array}{c}\text { Awn } \\
\text { length } \\
\text { (mm) }\end{array}$ & $\begin{array}{c}\text { Flower } \\
\text { number/spikelet }\end{array}$ \\
\hline $\begin{array}{c}\text { Plants from field } \\
\text { observations }\end{array}$ & 130 & 38,66 & 15,97 & 5,01 & 1,92 & 4,61 & 10 & $4-8$ \\
\hline $\begin{array}{c}\text { Literature data } \\
\text { (Flora RSR, Vol. XI) }\end{array}$ & $25-50$ & $20-40$ & $8-11$ & 5 & - & - & $10-15$ & $4-5$ \\
\hline
\end{tabular}

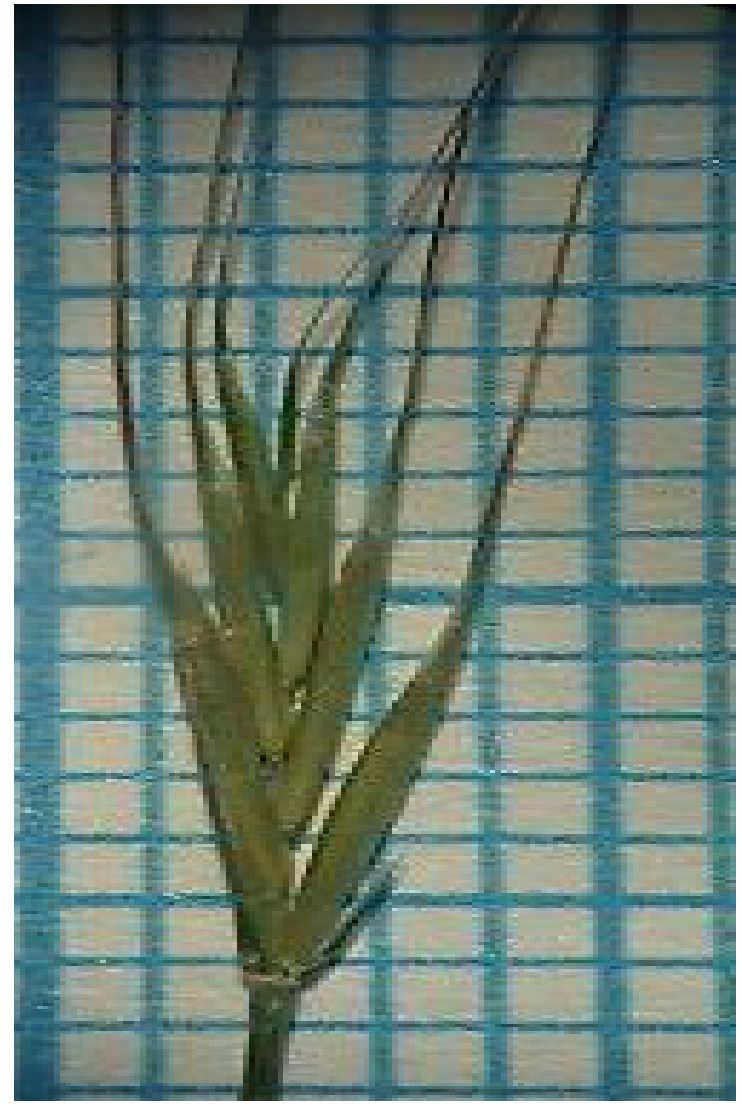

Figure 5. Vulpia myuros - spiklet with eight flowers

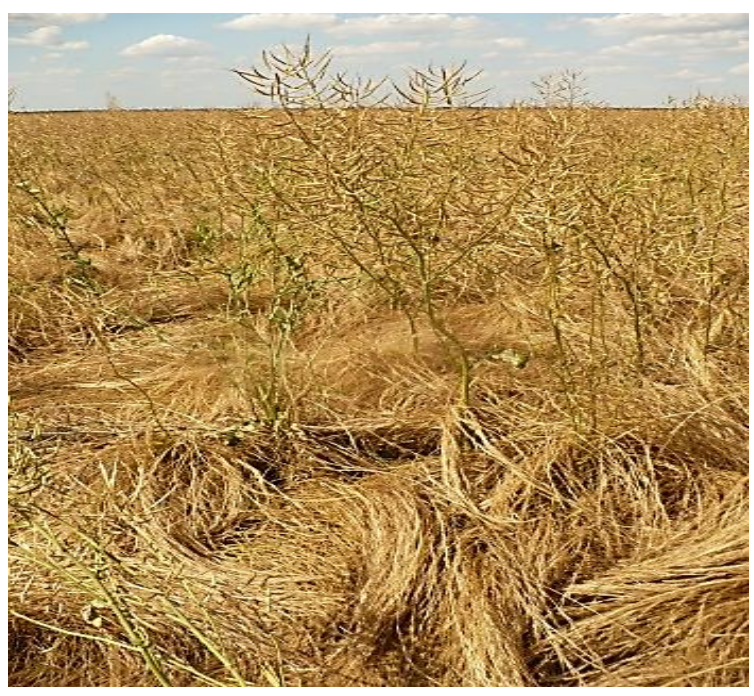

Figure 6. Mihăilești rape field in July

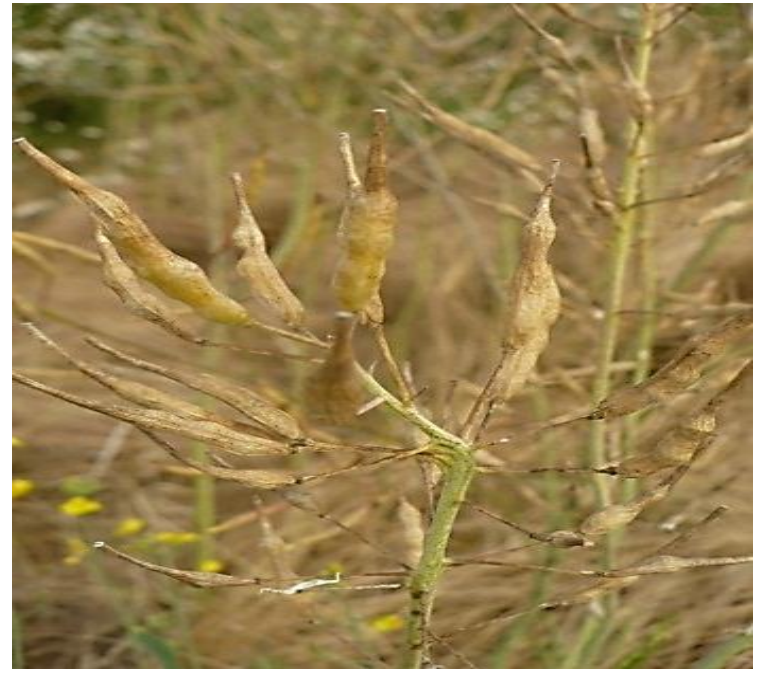

Figure 7. Silique at the end of growing season

It is obvious, by comparing the data in the table, the morphometric values of field plants are exceeding data recorded in the literature. Causes of this phenomenon may be multiple and we cannot pronounce until they have made several observations on the behavior of Vulpia myuros plants in rape crops. A spikelet with eight flowers from Vulpia myuros Mihăilești plants can be observed in Figure. 5.

An assessment made at the end of the growing season indicated that the density of rapeseed plants was about five $/ \mathrm{m}^{2}$ (Figure. 6, 7).

\section{Conclusions}

Our study reveals a new situation, unprecedented in the literature of our country, about the behavior of V.myuros as weed species in winter rape culture.

Comparing literature data with our field observations the establishment by direct seeding of rapeseed crops was the precondition for the severe harvest decrease.

Bare spots in the field have allowed the installation and then propagation of Vulpia myuros plants though the rapeseed crops are dense.

This observation leads us to expand our research in the future; issues that will be pursued are: area and cultures in our country where the species is present; existence of 
allopathic effects on rape plants; control options of V.myuros species populations through various methods etc.

\section{REFERENCES}

[1] Anastasiu P., Negrean G. (2008). New alien plants to Romania. Analele Univ. din Craiova. Seria Agricultură, Montanologie, Cadastru. 38/B: 1-10.

[2] Ball D.A., Frost M. S., Bennett L.H., Thill D.C., Rauch T., Jemett E., Mallory-Smith C., Cole C., Yenish J.P., Rood R. (2007). Control of Rattail Fescue (Vulpia myuros) in winter wheat. Weed Technology 21: 583-590.

[3] Ball D.A., Frost M. S., Fandich L., Tarasoff C., Mallory-Smith C. (2008). Biological attributes of Rattail Fescue (Vulpia myuros). Weed Science 56: 26-31.

[4] Burescu P., Pășcuț C.Gh. (2010). Inputs to knowledge of rocks vegetation within Codru Moma Mountains (NW Romania). Analele Univ. din Oradea - Fasc. Biol., Tom. XVII / 1: 62-69.

[5] Ciobanu I. (2010). Main meadows Subcarpathians Ialomița. Annals of "Valahia" University of Târgoviște: 75-79.

[6] Ciocârlan V., Berca M., Chirilă C., Coste I., Popescu Gh. (2004). Flora segetală a României. Ed. Ceres, Bucure ti.

[7] Ciocârlan V. (2009). Flora ilustrată a României. Ed. Ceres,
București.

[8] Chirilă C., Ciocârlan V., Berca M. (2002). Atlasul principalelor buruieni din România. Ed. Ceres, București.

[9] Ghișa E. (1972). Genul Vulpia K. C. Gmel. Flora Republicii Socialiste România, vol. XII. Ed. Acad. RSR, Bucure $\square$ ti: 454-457.

[10] Hull R., Mathiassen S.K., Moss S.R. (2011). Herbicidal control of Vulpia myuros (Rat's-tail fescue) in glasshouse screening tests. Aspects of Applied Biology: 75-81.

[11] Mathiassen S.K., Kudusk P., Heroriksen K.E. (2010). Control of Vulpia myuros in red fescue. IHSC2010oralproceedings.

[12] Min A., Pratley J.E., Haig T. (1993). The effect of soil on the phytotoxicity of residues of Vulpia myuros. „Farming - from paddock to plate" - Proceedings of the 7th Australian conference, 19-24 September 1993, The University of Adelaide, Adelaide, South Australia (w.w.w.survey.regional. org.//au/asa).

[13] Min A., Haig T., Pratley J.E. (2000). Phytotoxicity of Vulpia residues: Separation, identification, and quantitation of allelochemicals from Vulpia myuros. Journal of Chemical Ecology, vol. 26, no.6: 1465-1476.

[14] Nagodă E., Comănescu P., Anastasiu P. (2013). Phemeranthus confertiflorus: new alien species to Europe. J. Plant Develop. 20: 141-147.

[15] Sîrbu I., Stefan N., Oprea A. (2013). Plante vasculare din România. Ed. VictorBVictor, București. 